\title{
FINANCIAL INNOVATION AND EFFICIENCY OF FINANCIAL INTERMEDIATION IN NIGERIA
}

\author{
Jessie I. Chukwunulu ${ }^{1}$ and Steve N.O. Ibenta ${ }^{2}$ \\ ${ }^{1}$ Department of Banking and Finance, Chukwuemeka Odumegwu Ojukwu University, \\ Igbariam. \\ ${ }^{2}$ Department of Banking and Finance, Nnamdi Azikiwe University, Awka.
}

Cite this article:

J.I. Chukwunulu, S.N.O. Ibenta (2021), Financial Innovation and Efficiency of Financial Intermediation in Nigeria. African Journal of Accounting and Financial Research 4(2), 77-87. DOI: 10.52589/AJAFRMFZIZEEQ.

\section{Manuscript History}

Received: 10 May 2021

Accepted: 27 May 2021

Published: 7 June 2021

Copyright $(92020$ The Author(s). This is an Open Access article distributed under the terms of Creative Commons AttributionNonCommercial-NoDerivatives 4.0 International (CC BY-NC-ND $4.0)$, which permits anyone to share, use, reproduce and redistribute in any medium, provided the original author and source are credited.
ABSTRACT: This study investigated the effect of financial innovation on efficiency of financial intermediation of commercial banks in Nigerian between 2008 and 2018. The study used secondary data obtained from the Annual reports and Accounts of the Central Bank of Nigeria (CBN). The explanatory variables of the study are the product innovations in the banking sector namely: volume of automated teller machine transactions (ATM), volume of point-of-sale transactions (PoS), volume of Internet banking transactions (IBT) and volume of Mobile banking transactions $(M B T)$. The dependent variable is the financial intermediation efficiency proxied by interest rate spread, which is measured by the difference between maximum lending rate and savings rate. A multiple regression model developed for the study was analysed with the help of Ordinary Least Square (OLS) regression technique. The result from the descriptive statistics indicated that financial intermediation in Nigeria is inefficient. The results showed that ATM, IBT and MBT have insignificant positive effects on financial intermediation while PoS has negative effects on financial intermediation efficiency. Further results indicated that the $57 \%$ change in financial intermediation efficiency explained by financial innovation is not statistically significant. The study therefore concluded that financial innovation in itself is not a determinant of the efficiency of the intermediation process in Nigeria. It is then recommended that the regulatory authority among others should make policies to increase the savings rate, so that the surplus unit will be encouraged to make their funds available to the banks for lending.

KEYWORDS: Financial Innovation, Financial Intermediation, Interest Rate Spread, Product Innovation. 


\section{INTRODUCTION}

\section{Background to the Study}

The dominant feature of the modern financial system is a high pace of innovations, both in terms of their number and value. In less than a decade, there has been a significant increase in the number of alternative channels available for the delivery of financial services in Nigeria. Traditional delivery methods have given way to new delivery technologies which include ebanking products such as internet banking, mobile banking and various automated teller machine (ATM) products. Banks have collaborated with hardware, software and telecommunication companies in introducing new ways for consumers to access their account balances, transfer funds, pay bills, and buy goods and services without using cash, cheques or leaving their homes (Frei \& Kalakota, 1998). Adoption of these non-cash modes of payment has experienced continuous growth and this calls for an in-depth study to establish the effect of these financial innovations on the financial sector. These innovations, according to Sweeney and Morrison (2004), have changed the nature and process of retail banking as far as the delivery of financial services is concerned.

A basic function of financial innovation is in regard to credit generation which increases the amount of loanable funds available to deficit units, and generation of instruments which provides access to additional sources of equity capital (Ionescu \& Romania, 2012). The ultimate criterion when evaluating the effect of financial innovation in the banking sector is the extent to which it increases the efficiency of financial intermediation. As with innovations in other industries, financial firms can invent a brand-new class of products (financial instruments, techniques and markets), modify existing products, or combine the characteristics of several different products, thereby making financial intermediation more efficient and thus improving the availability of funds for business activities (Llewellyn, 1992). Financial intermediation is a process of channelling funds from surplus economic units to deficit economic units by financial institutions - the intermediaries. Thus, with financial intermediation, mobilization and allocation of investible funds become very simple. The intermediary matches the deposit requirements of the saver with the investment requirements of the borrower. He acts as a pool, collecting savings of different sizes from different categories of savers and meeting the investment needs of the various types of investors. The overall economic effect is that financial intermediation leads to a better aggregation of savings and therefore helps in capital formation and investment in the economy (Afolabi, 1988). The extent to which the financial sector can make contributions to the economy depends, to a large extent, on the quality and quantity of the products and services it offers customers. Business entities wishing to restore customer confidence need to focus on innovative products that meet their customers' specific needs (Kumar, 2011). The benefits offered by banking innovations are twofold: banks relish cost reduction and market expansion while customers enjoy a wide range of services/products and convenient banking. Financial intermediation invariably is affected by financial innovations and this intermediation is the core function of the financial sector. Financial innovation has the primary role of improving the intermediation process. It is expected to raise the efficiency of financial intermediation by enhancing funds mobilization and increasing the variety of financial products/services in order to eliminate any mismatch between savings and investment (Mishra, 2008). Innovations provide an impetus for banks to improve their market performance by recovering from palpable inefficiencies prevalent in the banking industry, as is the case in Nigeria and other emerging countries (Frimpong, 2010). For 
this reason, the effective working of the financial intermediation process is inherently a matter of public interest (Corrigan \& Gerald, 2004).

\section{Statement of the Problem}

The banks are mainly involved in financial intermediation, which involves channelling funds from the surplus units to the deficit units of the economy, thus transforming bank deposits into loans or credits (Bencivenga \& Smith, 1991). The review of studies shows that financial innovations in the banking sector are expected to improve the efficiency of financial intermediation (Domeher, Frimpong \& Appiah, 2014; Muiruri \& Ngari, 2014; Beck, Chen, Lin \& Song, 2012; Achieng, Karani \& Tabitha, 2015). However, the theoretical review was based on the traditional Arrow Debreu model of financial intermediation theory, which noted that efficient financial intermediation serves to reduce transaction costs, risks and informational asymmetries, and this is expected to facilitate the process of lending and borrowing for increased and improved productive activity in the economy. Thus, an efficient financial intermediation leads to a high level of employment generation and income which invariably enhances the level of economic development (Nwite, 2014). According to this study, several financial reforms have been put in place by successive governments to remove the restrictions militating against efficient financial intermediation in Nigeria. But in spite of all these efforts, lending rate has remained persistently high while credit to the private sector has remained low. With the wide gap between maximum lending rate and saving rate in Nigeria which causes high interest rate spread, it is clear that Nigerian banking intermediation process is inefficient. This study thus seeks to investigate the extent to which the current financial innovations can influence financial intermediation efficiency of commercial banks in Nigeria.

The dearth of extant empirical studies on the effect of financial innovations on the efficiency of financial intermediation calls for a study in the area. Vergas (2009) carried out a study in this area in Costa Rica. Dabwor (2010) investigated the challenges of financial intermediation in 21st Century Nigeria. Dijkstra (1996) studied financial reforms and efficiency of financial intermediation in Hungary. Empirical reviews show that studies that directly try to associate financial intermediation efficiency with financial innovation in Nigeria are scarce. Existing studies mainly focused on the effect financial innovation on the performance of commercial banks in Nigeria as well as other countries (Adele \& Akanbi, 2012; Mugo, 2012; Muiruri \& Ngari, 2014; Akhisar, Tunay \& Tunay, 2015; Kamau \& Oluoch, 2016); others focused on the effect of financial innovation on economic growth or welfare of the citizenry (Onodugo, Kalu \& Anowor, 2013; Nwite, 2014; Igbanibo \& Iwedi, 2015; Casadas, 2015; Ovidu, Seyed \& Alina, 2015). Considering the importance of fund mobilization and allocation in economic growth and development (the core function of financial intermediation), the specific objective of this study therefore is to find out whether the use of product financial innovation-ATM, PoS, Internet banking and Mobile banking - has actually improved the efficiency of financial intermediation in Nigeria.

The study focused on the volume of financial product innovations adopted in the banking system of Nigeria and used between 2008 and 2018. These include use of ATM, Internet banking, Point of Sale, and Mobile banking. 


\section{CONCEPTUAL LITERATURE}

\section{Financial Intermediation}

Financial intermediation is a process by which funds are mobilized and transferred from surplus economic units to deficit units. Funds are taken from a depositor and lent to a borrower. Financial intermediation is the core activity of the financial intermediaries. The most common intermediaries are banks; they mobilize deposit liabilities and transform them into bank assets or credits such as loans and overdraft to companies that need resources for investment (Andrew \& Osuji, 2013). The banking business thrives on the financial intermediation abilities of the financial institution that allow them to lend out money at relatively high rates of interest, while receiving money on deposit at relatively low rates. This spread, which is the difference between the interest paid to depositors and the interest charged on borrowers, constitutes the profit of the banks. Financial intermediation procaee is informed by the need to channel funds where they will yield the highest social return.

\section{Financial Innovation}

In the words of Targalski (2006) cited in Błach (2011), the term "innovation" was used to describe the changes in the technological solutions, creating new combinations of productive means, generating the above-the-average rates of return and thus enhancing the dynamic development of the overall economy.

Financial innovations are changes in the financial system alone. In the words of Frame and White (2002) financial innovation is "... something new that reduces costs, reduces risks or provides an improved product/service/instrument that better satisfies participants' demands...within a financial system." Innovations can emerge due to technological changes as well as a response to increased risk or to new regulations. According to Mmolainyane (2015), financial innovation demonstrates the financial market's management strategies that provide resilient innovative products that are tailor-made to the local market and more open than government policies, by encouraging private sector participation.

Błach (2011) noted that financial innovation can be defined in a narrow as well as a broad sense. In the narrow approach of financial innovations, he defined it as any new development in financial instruments (entirely new instruments, combination of traditional instruments, modification of traditional instruments, new application of existing instruments, etc.). In the broad approach however, financial innovation includes any new development in any element of the financial system (markets, institutions, instruments and regulations). According to Lawrence and Scott (2001), as cited in Achieng, Karani and Tabitha (2015), financial innovation is a broad concept covering areas that include usage of new financial intermediation methods, foundation of new financial institutions, changes in legislation or financial supervision, changes in business processes and changes in services such as new deposits and loan products, derivative instruments, insurance and investment products. These innovations emerge because they enhance the efficiency of the functions performed by financial intermediaries under changing circumstances through the design of new instruments, techniques, institutional arrangements and markets, or by unbundling and repackaging characteristics of existing products and practices (Battilossi, 2000).

According to Allan and Gale (1994) as cited in Achieng et al. (2015), the benefits of financial innovation include avoiding regulations and optimizing taxes, reducing transaction costs and 
increasing liquidity of market based products, reducing agency costs between executive management and shareholders and between shareholders and creditors, reducing informational asymmetry between corporate insiders and outsiders, increasing risk sharing opportunities, and making capital intermediation more efficient and cheaper for clients.

When defining financial innovation, the usual approach is to categorize it into three groups, according to where innovation occurs (Vargas, 2009).

Process innovation refers to new production processes that allow the provision of new or existing financial products and services. Two examples commonly cited are loan tracking systems and credit scoring. Process innovation is usually aimed at increasing the efficiency of the production process, and it is often associated with technological change.

Organizational innovation encompasses new institutions or organizational structures within institutions where the production process is held. This kind of institutional innovation can influence the financial system as a whole, spawning new types of intermediaries. Internet-only banking is a prime example of this type of innovation.

Product innovations are new products or services created to meet market needs, thus constituting a client-focused kind of financial innovation. Product innovations help the intermediaries by granting them competitive advantage in the market through the provision of solutions to unattended needs of the customers. Examples of product innovations in finance are widespread from adjustable-rate mortgages to home equity loans, from variable rate bonds to zero-coupon bonds.

In line with Battilossi (2000), the financial innovations adopted are analysed here as a process of incentives and responses to changes in the economic and regulatory environment (either domestic or international), through which bank managements have designed new products, techniques or institutional arrangements to perform international functions.

\section{Theoretical Framework}

This study is anchored on the theory of financial intermediation. The goal of intermediation theory is to explain how financial intermediaries exist. According to the traditional Arrow Debreu model of resource allocation, firms and households interact through markets and financial intermediaries play no role (Allen \& Santomero, 1998). This theory posits that when markets are perfect and complete, the allocation of resources is Pareto efficient and there is no scope for intermediaries to improve welfare. A traditional criticism of this standard marketbased theory is that a large number of securities is needed for it to hold, except in special cases. The advent of financial innovation has reintroduced this theory as modern intermediation theory. The modern theory borrows from the roles of financial innovation in reading the cost of transaction and information asymmetry in the financial system (Scholtens \& van Wensveen, 2013). The theory explains that financial intermediaries are active because market imperfections prevent savers and investors from trading directly with each other in an optimal way. The most important market imperfections are the informational asymmetries between savers and investors. Financial intermediaries, banks specifically, as agents and as delegated monitors, fill this information gap between ultimate savers and investors. This is because they have a comparative informational advantage over ultimate savers and investors. They screen and monitor investors on behalf of savers. This is their basic function, which justifies the transaction costs they charge to parties. They also bridge the maturity mismatch between savers 
and investors and facilitate payments between economic parties by providing a payment, settlement and clearing system. Consequently, they engage in qualitative asset transformation activities. Thus, current financial intermediation theory builds on the notion that intermediaries serve to reduce transaction costs and informational asymmetries. As developments in information technology, deregulation, deepening of financial markets, etc. tend to reduce transaction costs and informational asymmetries, financial intermediation theory comes to the conclusion that intermediation becomes useless. As soon as markets are perfect, intermediaries become redundant; they will lose their function because savers and investors can access the perfect information needed to find each other directly, immediately and without any impediments or costs, and to deal at optimal prices.

\section{METHODOLOGY}

The study used secondary data obtained from the CBN Annual Reports and Accounts. The annual time series data spans eight (8) years from 2008 to 2015. The variables of the study are Interest Rate Spread, volume of ATM transactions, volume of PoS transaction, volume of Internet banking transaction and volume of Mobile banking transaction.

\section{Model specification}

The model is derived from the work of Akhisar, Tunay and Tunay (2015) that used number of bank cards, number of existing PoS terminals, the ratio of ATM to number of branches, and number of customers who benefit from internet banking services. However, these variables were not available in Nigeria. This study therefore used volume of ATM transactions, volume of PoS transaction, volume of Internet banking transaction and volume of Mobile banking transaction as explanatory variables (financial innovations). Interest rate spread, which is measured by the difference between maximum lending rate and deposit rate, indicates the level of efficiency of the banking sector as well as the level of development of the financial system. The theoretical proposition is that financial innovations would improve the efficiency of financial intermediation. Thus, the functional relationship of the model is as follows:

IRS = f(ATM, PoS, IBT, MBT)

where: IRS = Interest rate spread as a proxy for financial intermediation efficiency

$\mathrm{ATM}=$ the volume of transactions done through the ATM machine

$\mathrm{PoS}=$ the volume of transactions done through the PoS channel

IBT $=$ the volume of transactions performed through Internet banking innovation

$\mathrm{MBT}=$ the volume of transactions performed through Mobile banking innovation

The model can be rewritten as an equation thus:

$\mathrm{IRS}=\alpha_{0}+\beta_{1} \mathrm{ATM}+\beta_{2} \mathrm{PoS}+\beta_{3} \mathrm{IBT}+\beta_{4} \mathrm{MBT}+\mu$

Where: $\alpha_{0}$ is the constant, $\beta_{1-4}$ are the coefficients of the explanatory variables while $\mu$ is an error term. 


\section{Method of Data Analyses}

The OLS regression technique was employed because it has the criteria of being Best Linear Unbiased Estimator of linear relationship like the one employed in this study. The coefficient of determination $\left(\mathrm{R}^{2}\right)$, F-test, t-test, beta and Durbin-Watson were used in the interpretation of the results. The SPSS 20 (specialised computer package for running statistical analysis) was used to regress the variables of financial innovation (ATM, PoS, IBT and MBT) on the dependent variable - financial intermediation efficiency.

The decision rule for test of hypotheses is to reject the null hypotheses for calculated significance value below 5\% level of significance. The Coefficient of Determination $\left(\mathrm{R}^{2}\right)$ measures the explanatory power of the independent variables on the dependent variable. The $r^{2}$ normally makes an overestimation of the true value of the population, especially when a small sample is used. The Adjusted $\mathrm{r}^{2}$ corrects this problem (Pallant, 2004). Therefore, since the sample of the study is a small one, Adjusted $r^{2}$ is used. F-Test measures the overall significance. Student T-Test measures the individual significance of the estimated independent variables. The beta (the standardised coefficient) is also used to measure the individual contribution of the variables to variation in the dependent variable. Durbin Watson (DW) Statistics test is used for autocorrelation in the regression.

Table 1: Model Estimation

Coefficients $^{\mathbf{a}}$

\begin{tabular}{|c|c|c|c|c|c|c|}
\hline \multirow{2}{*}{\multicolumn{2}{|c|}{ Model }} & \multicolumn{2}{|c|}{ Unstandardized Coefficients } & \multirow{2}{*}{$\begin{array}{c}\begin{array}{c}\text { Standardized } \\
\text { Coefficients }\end{array} \\
\text { Beta }\end{array}$} & \multirow[t]{2}{*}{$\mathrm{t}$} & \multirow[t]{2}{*}{ Sig. } \\
\hline & & $\mathrm{B}$ & Std. Error & & & \\
\hline \multirow{5}{*}{1} & (Constant) & 15.251 & 2.175 & & 7.013 & .006 \\
\hline & ATM & .018 & .007 & 1.046 & 2.420 & .094 \\
\hline & PoS & -.611 & .746 & -2.338 & -.819 & .473 \\
\hline & IBT & .274 & .350 & .237 & .783 & .491 \\
\hline & MBT & .414 & .501 & 2.163 & .826 & .469 \\
\hline \multicolumn{7}{|c|}{$\begin{array}{l}\text { Coefficient of Determination }\left(\mathrm{R}^{2}\right)=0.817 \\
\text { Adjusted } \mathrm{R}^{2}=0.573 \\
\text { Durbin-Watson }=2.063 \\
\text { F-statistics }=3.346 \\
\text { F-prob. }=.174\end{array}$} \\
\hline
\end{tabular}

Dependent Variable: IRS

Predictors: (Constant), MBT, IBT, ATM, PoS

The result of model estimation is shown on Table 1 above. The value of adjusted coefficient of determination suggests that about $57 \%$ of changes in bank intermediation efficiency can be explained by financial innovation (ATM, PoS, IBT and MBT). However, the F-statistics (3.346) with probability (0.174) which is greater than 0.05 level of significance indicate that financial innovation variables do not have significant effect on financial intermediation efficiency in Nigeria. The model that produced this result is confirmed to be reliable with a 
Durbin-Watson statistics of 2.063. The coefficient of regression can be used to write the equation of the relationship in the model as follows:

$\mathrm{IRS}=\alpha_{0}+.018 \mathrm{ATM}-.611 \mathrm{PoS}+.274 \mathrm{IBT}+.414 \mathrm{MBT}$

The equation shows that ATM, IBT and MBT can have positive relationships with financial intermediation in Nigeria. The results of the $t$-statistics are ATM $(t=2.420, p=.094), \operatorname{PoS}(t$ $=-.819, \mathrm{p}=.473)$, IBT $(\mathrm{t}=.783, \mathrm{p}=.491)$ and MBT $(\mathrm{t}=.826, \mathrm{p}=.469)$. The results show that all the p-values are above 0.05 level of significance. Thus, all the variables of financial innovation (ATM, PoS, IBT and MBT) do not have significant effects on financial intermediation efficiency in Nigeria.

\section{SUMMARY OF FINDINGS}

The major findings of the study can be summarised as follows:

1. A high interest rate spread (difference between maximum lending rate and savings rate) is suggestive of inefficient financial intermediation in Nigeria. This finding is in line with the findings of Nwite (2014) that saving is discouraged among Nigerians due to low returns on deposits. This impairs lending activities and investment potential as a result of high cost of funding.

2. Coefficient of determination suggests that $57 \%$ of changes in bank intermediation efficiency can be explained by financial innovation (ATM, PoS, IBT and MBT).

3. The F-statistics indicate that financial innovation variables do not have significant effects on financial intermediation efficiency in Nigeria.

4. The results of the coefficient of regression and t-statistics indicate that use of ATM innovation has a positive but insignificant effect on financial intermediation efficiency.

5. The results of the coefficient of regression and t-statistics indicate that use of PoS innovation has a negative but insignificant effect on financial intermediation efficiency.

6. Also, the results of the coefficient of regression and t-statistics indicate that use of internet banking innovation has a positive but insignificant effect on financial intermediation efficiency.

7. Finally, the results of the coefficient of regression and t-statistics indicate that use of mobile banking innovation has a positive but insignificant effect on financial intermediation efficiency.

\section{CONCLUSION AND RECOMMENDATIONS}

The study investigated the effect of financial innovation on the efficiency of financial intermediation in Nigeria from 2008 to 2015. The results show that the use of financial innovation products has grown over the years but the intermediation process has remained inefficient, as evidenced by high interest rate spread. This suggests that banks make excess 
profits from their intermediation function. However, the estimated model has shown that financial innovation has no significant effect on intermediation efficiency in Nigeria. Thus the study posits that financial innovation in itself is not a determinant of the efficiency of the intermediation process in Nigeria.

The study therefore recommends that the regulatory authorities need to formulate policies that will increase the savings rate, so that the surplus units will be encouraged to avail their funds to the banks for lending. Also, measures that will regulate the margin of profit from lending should be adopted. This could help to enhance financial intermediation efficiency in Nigeria.

\section{REFERENCES}

Achieng, O. C., Karani, K. P.\& Tabitha, N. (2015). Financial Innovation and the Future of Financial Intermediation.International Journal of Education and Research, 3(5), 385 392.

Adele, H. A.\&Akanbi, T. A. (2012). Effects of new financial products on the performance of selected commercial banks in Nigeria. Research Journal of Finance and Accounting, 3(7), $45-54$.

Afolabi, L.(1998). Monetary Economics.Lagos: Perry Barr Limited.

Akhisar, I., Tunay, K. B.\&Tunay, N. (2015). The Effects of Innovations on Bank Performance: The Case of Electronic Banking Services. Social and Behavioral Sciences 195 ( 2015 ) 369 - 375. doi:10.1016/j.sbspro.2015.06.336.

Akinlo, A.E.. \& Owoyemi. B.O. (2012) The Determinants of Interest Rate Spread in Nigeria: An Empirical Investigation. Modern Economy 3(7) 837-845.

Allen, F. \&Santomero, A. M. (1998). The theory of financial intermediation. Journal of Banking and Finance, 21, 1461- 1485.

Andrew, O.A \& Osuji, C.C. (2013). An Empirical Analysis of Financial Intermediation and Output in Nigeria. Global Journal Inc (USA) 13(9). 210-216.

Battilossi, S. (2000). Financial innovation and the golden ages of international banking: 1890-1931 and 1958-81.Financial History Review, 7, 141-175.

Bencivenga, V. R. \& Smith, B. D.(1991). Financial Intermediation and EndogenousGrowth. Review of Economics Studies, 58, 195-209.

Błach, J. (2011). Financial innovations and their role in the modern financial system identification and systematization of the problem. Financial Internet Quarterly, 7(3), 13 $-26$.

Casadas, P. V. (2015). Innovation for financial access and its impact in financial intermediation and poverty reduction. Working Paper \# 2015/19. Retrieved from https://www.uam.es/docencia/degin/catedra/documentos/19_Innovation\%20for\%20fina ncial\%20access\%20and\%20its\%20impact\%20in\%20financial\%20intermediation\%20an d\%20poverty\%20reduction.pdf

Corrigan, E. Gerald (2004), Large Integrated Financial Intermediaries and the Public Interest, Goldman, Sachs \& Co., April.

Dabwor, T.D. (2010). The Nigerian Banking System and the Challenges of the Financial Intermediation in the $21^{\text {st }}$ Century. Jos Journal of Economics 4(1). 
Domeher, D. Frimpong, J.M. \& Appiah, T. (2014). Adoption of Financial Innovation in the Ghanaian Banking Industry. Afrjcan Journal of Economics and Finance 6(2). 88-114.

Frame, W. Scott \& White, Lawrence J. (2002). Empirical Studies of FinancialInnovation: Lots of Talk, Little Action? (Working Paper 2002-12). Atlanta, GA, USA: Federal Reserve Bank of Atlanta.

Frei, F.X. and Kalakota, R. (1998). 'Frontiers of online financial services', in Cronin, M.J. (ed.). Banking and finance on the Internet, Van Nostrand Reinhold Press, New York.

Frimpong, J.M. (2010). 'Investigating efficiency of Ghana banks: A non-parametric approach', American Journal of Scientific Research, vol. 7, pp. 64-76.

Gorton, G. and Winton A. (2002) Financial Intermediation, Working Paper 8928, http://www.nber.org/papers/w8928

Igbanibo, D. A. \&Iwedi, M. (2015). The intermediation functions of finance companies and economic growth: Issues, theory and empirical evidence from Nigeria. Journal of Finance and Accounting, 3(3), 47-56.

Ionescu, C \& Romania, B. (2012). Financial Instability and Financial Innovation: Economy Transdisciplinary Cognition 15(2), 30-37.

Kamau, D. M.\&Oluoch, J. (2016). Relationship between financial innovation and commercial bank performance in Kenya. International Journal of Social Science and Information Technology, II(IV), $576-594$.

Kumar, K.S.V. (2011). 'Innovations in modern banking and innovative financial inclusion issues and challenges', CLEAR IJRCM, vol. 1, no. 2 (Jul-Dec), pp. 147-196.

Llewellyn, D. (1992). 'Financial innovation: A basic analysis', in Cavanna, H. (ed.). Financial innovation, Routledge, London.

Mishra, P.K. (2008). Financial Innovation and Economic Growth - A Functional Approach; Retrieved from: SSRN

Mmolainyane, K. K., \& Ahmed, A. D. (2015). The impact of financial integration in Botswana. Journal of Policy Modeling.

Mugo, J. G. (2012).The effect of financial innovation onthe growth of micro-finance institutions in Kenya. A Research Project Report Submitted in Partial Fulfilment of the Requirements for the Award of the Degree of Master of Business Administration, School Of Business, University of Nairobi.

Muiruri, J. K.\&Ngari, J. M. (2014).Effects of Financial Innovations on the Financial Performance of Commercial Banks in Kenya.International Journal of Humanities and Social Science, 4(7), $51-57$.

Nwite, S. C. (2014). Determinants of financial intermediation and its implications on economic growth in Nigeria. British Journal of Marketing Studies, 3(9), 49-56.

Onodugo, V. A., Kalu, I. E.\&Anowor (2013). Financial Intermediation and Private Sector Investment in Nigeria. Research Journal of Finance and Accounting, 4(12) 47 - 54.

Scholtens, B. \& van Wensveen, D. (2013). The Theory of Financial Intermediation: An Essay On What It Does (Not) Explain. SUERF - The European Money and Finance Forum. Vienna.

Shittu, A. (2012). Financial Intermediation and Economic Growth in Nigeria. British Journal of Arts and Social Sciences, 4(2), 1-10. 
African Journal of Accounting and Financial Research

ISSN: 2682-6690

Volume 4, Issue 2, 2021 (pp. 77-87)

www.abjournals.org

Stoica, O, Mehdian, S \& Sargu, A. (2015). The Impact of Internet Banking on the Performance of Romanian Banks. DEA \& PCA Approach. Procedia Economics and Finance, 20. 610-622.

Sweeney, A. and Morrison, M. (2004). 'Clicks vs. bricks: Internet-facilitated relationships in financial services', International Journal of Internet Marketing and Advertising, 1(4), $350-370$.

Vergas, A. R. (2009). Assessing the contribution of financial innovations to the production of implicit services of financial intermediation in Costa Rica. IFC Bulletin No 31, 455466. 